\title{
Research on Improving the Teaching Effect of Legal Education of Entrepreneurship in Colleges and Universities
}

\author{
Hong-Zhen LIN ${ }^{1, a^{*}}$, Chen ZHANG ${ }^{1}$, , Jing-Yi WAN ${ }^{1, c}$, Jia-Min MA ${ }^{1, d}$, \\ 1School of Hengda Management, Wuhan University of Science and Technology Wuhan, China \\ 947 He Ping Street, Hubei Wuhan 430081, China \\ alinhongzhen@126.com, b $542557052 @ q q . c o m,{ }^{c} 516130571 @ q q . c o m,{ }^{d} 1115243090 @ q q . c o m$
}

Key words: Legal education, Entrepreneurship risk, Curriculum system.

\begin{abstract}
The purpose of this paper is to research the Improving the Teaching Effect of Legal Education of Entrepreneurship in Colleges and Universities. Using the method of questionnaires and interviews, document study deeply, correctly understand and analyze the problem of bad teaching effect of legal education of entrepreneurship. the low success rate of College Students' entrepreneurship is due to their weak awareness of the law and lack of legal capacity. It is urgent to strengthen the proportion of legal education in university students' entrepreneurship education system. Based on the analysis of the current situation of entrepreneurship education in our country, the overall education in Colleges and universities, this paper proposes improvement measures. The conclusion is that In the light of the legal risk in the process of entrepreneurship, we should put forward the curriculum system of legal education that runs through the whole learning stage, and hopes to provide legal support for college students in Colleges and universities, guides the legitimate entrepreneurship of college students, establishes risk prevention awareness, and improves their legal attainment and legal ability.
\end{abstract}

\section{Introduction}

Innovation and entrepreneurship education is often called "double creation education", which refers to a new teaching idea and model in order to adapt to the social development and the needs of the national strategic planning. Innovation and entrepreneurship education emphasizes the cultivation of talents from many aspects, among which legal literacy is an essential part of talent training plan. In 2015, the slogan of "mass innovation and all kinds of entrepreneurship" was put forward. The importance of entrepreneurship education was emphasized. Entrepreneurship Education in Colleges and universities not only aims at solving the problem of employment in the country, but also promotes the society to form a good atmosphere. An important part of entrepreneurship education is the legal education. Through imparting the knowledge of entrepreneurship, the legal education of entrepreneurship make the students master the necessary legal knowledge and certain legal skills. In addition, the student can form a good sense of law, and set up a correct legal concept. Besides using the law correctly in the process of entrepreneurship helps the entrepreneurs consciously abide by the law and improve entrepreneurial ability and adapt to the current employment needs of society. But the current legal education system is not perfect, and the problem of legal education marginalization is more prominent. The students' legal literacy is generally low, which cannot meet the requirements of the state for the legal education of entrepreneurship. So it is urgent to promote the reform of the legal education of entrepreneurship at present.

\section{The Main Problems of the Teaching of Entrepreneurship Law}

\section{Firstly, Lack of Legal Concepts in the Process of Entrepreneurship Education}

The development of entrepreneurship education in China has been gradually improved, however it has not developed a systematic system. Now the focus is how to cultivate the students' entrepreneurial ability, enhance the students' entrepreneurial consciousness and innovation ability. In order to investigate the degree of College Students' understanding about the law of 
entrepreneurship and understand the status of the legal education of entrepreneurship in China, so that we can explore how to strengthen the legal education, the author conducted a questionnaire survey entitled "the understanding of the legal risk of entrepreneurship and entrepreneurship for college students". In the questionnaire survey, the author showed that the college students thought the main predicament is the misunderstanding of the knowledge of entrepreneurship education. and the education put more emphasis on the imparting of entrepreneurial skills than the cultivation of entrepreneurial spirit, and the legal education of entrepreneurship is not taken seriously. The results of this survey show that college students generally think that colleges and universities are not paying enough attention to the legal education of entrepreneurship at present, and the legal education of entrepreneurship is gradually becoming "marginalized", which cannot achieve the ultimate requirement of enhancing students' legal literacy.

\section{Secondly, Backward and Single Teaching Content}

There are also some problems in the teaching content of some legal courses that have been set up in entrepreneurship education. First of all, most of the cases as the legal knowledge of the explanation in the classroom, are the teaching of the specific provisions in the law instead of the proportion of the case study, then the legal provisions cannot be combined with the practice. In addition, the legal education of entrepreneurship should eventually return to the basic point of "entrepreneurship", so the legal education should be close to the main direction of entrepreneurship. But considering the limitations of entrepreneurial practice, there are few real teachers who have experienced entrepreneurship, as a result the legal examples related to entrepreneurship are scarce. [1]Thus, it is a "pain point" that the legal education cannot be combined with the real combination of law and entrepreneurship. There are not enough attention to legal education in entrepreneurship law education. And the direction of legal courses is narrow, lack of diversity, and does not form a systematic system. Due to the true that several legal aspects involved cannot be linked to a close whole, and the legal knowledge is not comprehensive enough, so we said the content of education is "one-sided".

\section{Thirdly, Weak Teacher Resources}

The legal education of entrepreneurship requires teachers to combine the basic knowledge of entrepreneurship, professional knowledge and legal knowledge to the students. We always hope that the teacher's knowledge system is systematic, so the professionalism for teachers is more and more stronger. At present, the entrepreneurial tutor is composed of teachers of the school of economics and management, the law profession or who work with the students. They have greater diversity among professional and focus on the research in their own field. The practice experience is less and the attention to the business is not enough. In the course, it cannot be connected with the social environment and trend of social entrepreneurship in time. [2]It is not comprehensive to understand some specific policies and processes, and is closed to the dissemination of legal knowledge.

The legal education of entrepreneurship is the same as other aspects of entrepreneurship education, which is based on the traditional classroom teaching. The teachers are the dominant while the students are learning passively under the guidance of teachers. The teaching methods are relatively simple. The enthusiasm of learning is not high enough to experience real legal cases.

\section{The Way to Strengthen the Legal Education of Entrepreneurship in Colleges and Universities}

\section{Firstly, Improving the Importance of Legal Education}

Ruling the country according to law is China's basic national policy and it requires all market participants to abide by the law. As the innovative talents, college students are concerned about the state and society. It is necessary to understand Scientific Outlook on Development deeply, abide by laws and regulations consciously, and strengthen the legal accomplishment. College Students' entrepreneurship is not only the development of creativity, but also the transformation of creativity into achievement through commercial operation. 2 . Any mistakes made by university students in the 
process of entrepreneurship may be a failure. Therefore, the good development of an enterprise requires entrepreneurs to systematically analyze the legal risks of entrepreneurship, reasonably avoid them and enhance legal awareness. Colleges and universities should deeply recognize the importance of the legal education of entrepreneurship, and take the legal education into the system of entrepreneurship education, so that they can improve the status of the legal teaching in the whole process of entrepreneurship teaching and then form a curriculum system which is independent and interrelated with the entrepreneurship education. Universities should help the students to develop a custom that include learning law, respect the law, obedience of law and apply the law. The good habit of law and usage promotes college students' legal entrepreneurship and promotes the establishment of a legal society.

\section{Secondly, Strengthening the Construction of Teachers' Strength}

The legal education of entrepreneurship requires the introduction of specific case analysis through classroom analysis. Based on the analysis of cases, students can have experience in starting a business and avoid venture risks in time. Weakness of the teacher resources will reduce the effect of legal education on entrepreneurship. Colleges and universities can employ professional lawyers in the society as a part-time legal teacher, and they can hold regular lectures, forums and so on. This measures can broaden the way for students to learn the law of entrepreneurship. Colleges and universities should encourage teachers to carry out and participate in seminars on entrepreneurship legal education. So teachers using this method can continuously exchange learning and strengthen entrepreneurship teacher resources. At the same time, we can actively cooperate with the enterprise. Once collages strengthen the connection with the enterprise, then they can invite successful personages of enterprises to guide and lecture for students, provide students with internship opportunities so that student make truly experience the risks faced by the real enterprises and increase the students' experience in solving practical legal problems.

\section{Thirdly, Reinforcing Practice Teaching}

Most of the contents in the classroom are based on theory. We can make use of the entrepreneurial competition to enhance the practice teaching. To a certain extent, it helps students to acquire some practical skills, promote the students to learn entrepreneurial knowledge, and help to improve the conversion rate of entrepreneurial opportunities. [3]In order to emphasize the importance of entrepreneurial legal education in entrepreneurship education, it can be added to the assessment of the legal environment in the competition requirements. The competition will more truly be close to the actual situation of entrepreneurship to encourage students to learn the legal knowledge involved in the business initiative and improve students' legal literacy.

Another way is to combine the entrepreneurial clinic with the classroom according to the actual situation of the University, and form a scientific legal education mode of entrepreneurship. The education model of "venture clinic" is divided into two stages. In the first stage, after learning basic knowledge, students use the law clinic to carry out simulated practice training, take part in curriculum teaching and case analysis. Then they can strengthen the understanding and digestion of basic entrepreneurial knowledge. The second stage is that students have mastered some certain entrepreneurial legal knowledge. After that, the students who studied in the legal clinic are arranged to enter the simulated business organization or the law firm to carry out the probation. In this way, students can fully understand the legal process of starting the start-up stage and the solution mechanism of legal disputes in the process of entrepreneurship. Finally, they can link the theory to practice and improved the legal skill level (3).

\section{Fourthly, Diversifying Teaching Resources}

Influenced by the educational system of universities in China, the most basic way of implementing legal education in Colleges and universities is traditional classroom teaching. Therefore, in order to enhance the effectiveness of legal entrepreneurship education, we should make good use of the classroom teaching. Teachers should cooperate with students actively. In class, teacher play a leading role. [4] Using the method of case, case simulation, chart and so on, they can stimulate 
students' enthusiasm for the study of legal knowledge step by step , improve students' learning efficiency and increase their learning efficiency.

With the development of network technology, more and more resources are constantly shared. There is no double that education in Colleges and universities need to follow the tide of the times. Education media cannot be limited to specific objects, and the convenience of network technology should be fully utilized. The school can refer to the opinion of the students that they can rely on the network to carry out legal education. [5]With the help of the mass media such as WeChat, micro-blog and news, the information can be integrated and screened, and the favorable information assisted instruction can be screened to improve the students' legal cognition and risk prevention and control ability.

\section{Fifthly, Optimizing the Legal Curriculum System}

In order to achieve a significant result, we need to lay out a basic curriculum system for entrepreneurial legal education in addition to classroom teaching. This paper makes a summary of the core curriculum content of the legal education for the college students in the different periods. [6]The periods is from the establishment of the enterprise, the management to the exit of the market.

The problems involved in the whole process of entrepreneurship are the rights and interests of the entrepreneurs themselves, and they are often overlooked, especially intellectual property rights. In the narrow sense of intellectual property, patent rights, trademark rights and copyright are included. [7]University students can use their own advantages to innovate under the basis of not infringing on other people's intellectual property rights and form their own advantages. But at the same time, students should protect their patent right, trademark right or copyright. Entrepreneurs should be clear about their own intellectual property rights and how to use legal means to protect their intellectual property rights from infringement.[8] they also need to know whether their rights and interests are infringed by others or whether other people's intellectual property rights are violated. The patent law, the trademark law and the copyright law, which are related to intellectual property rights, should be taught as a key content.

Disputes in the process of entrepreneurship can be derived from all aspects. Although disputes are constantly avoided, they should be correctly understood. To resolve disputes, the key is to handle the relationship between the two sides of the dispute well, and use legal methods to solve problems actively.[9] The laws adopted are "Civil Disputes Law" and "Arbitration Law". For some disputes or other forms of rights and interests, the ultimate goal is to make the entrepreneurs self-consciously keeping the law, improve their own legal accomplishment and to be a qualified good citizen through these problems.

\section{Conclusion}

The legal education of entrepreneurship is a very important link in the entrepreneurship education. The legal education of entrepreneurship can reduce the risk of entrepreneurship and improve the success rate of entrepreneurship. The success of the legal education of entrepreneurship is largely determined by the legal curriculum system. A good entrepreneurial law education curriculum should maintain a close relationship with the social entrepreneurship environment. Beyond that it is closely related to the curriculum system of our university, and should pay attention to the cultivation of students' legal consciousness and help students adapt to the needs of future entrepreneurship and development. There is still a certain gap between the current level of legal education and expectations in China, and it is necessary for universities and society to work together to build a more suitable legal education system which is more suitable for the development of the present business. 


\section{Acknowledgement}

This research was financially supported by National social science fund education general project "entrepreneurial law education research based on risk control in science and Engineering University ", No. BIA170192.

\section{Reference}

[1] Xu Xiaoxia, Ceng Jianpeng. Development dilemma and Countermeasures of entrepreneurship education in Chinese universities [J]. China Educational Technology and equipment, 2017 (7):7-8. In Chinese

[2] Wang Zhanren. The construction of a broad spectrum innovation and entrepreneurship education system on the development of [J]. education, 2012 (3): 54-58. In Chinese

[3] Hou Hui Jun, Lin Guangbin et al., Chinese University Entrepreneurship Education Blue Book student entrepreneurship education practice research [M], Economic Science Press, 2011,1-2. In Chinese

[4]Huang Zhaoxin. On several core issues in the transformation and development of entrepreneurship education in Colleges and universities [J]. Journal of Lanzhou University (SOCIAL SCIENCES), 2014, 42 (6): 147-154. In Chinese

[5]Ding Dan. Legal risks of College Students' Entrepreneurship and preventive measures [J]. innovation and entrepreneurship education, 2017, 8 (3): 63-65. In Chinese

[6]Xue Cheng, Xu Kefeng, Yang Bo. Legal education of innovation and entrepreneurship in science and Engineering University [J]. China Metallurgical Education, 2017 (1): 46-48. In Chinese

[7]Huang Jing, Liu Zifen. Analysis of legal education for college students in the context of "double creation" [J]. Journal of Changchun University, 2017, 27 (3): 107-109. In Chinese

[8] Peng Xinyan. Commentary on the research of entrepreneurship education mode in Chinese Universities under the new situation [J]. Social Sciences Section, 2016,31 (6): 166-169. In Chinese

[9] Jiang Deqin. On the quality evaluation system of innovation and entrepreneurship education in Colleges and Universities: [J]. innovation and entrepreneurship education, 2015,6 (6): 1-4. In Chinese 